\title{
Belippo eburnensis sp.n., a new ant-like jumping spider (Araneae: Salticidae) from western Africa
}

\section{Belippo eburnensis sp.n., новый вид пауков-скакунчиков (Araneae: Salticidae) из западной Африки}

\author{
Wanda Wesolowska ${ }^{1^{*}}$, Konrad Wiśniewski ${ }^{2}$ \\ Ванда Весоловска ${ }^{*}$, Конрад Вишневский ${ }^{2}$
}

\footnotetext{
${ }^{1}$ Department of Biodiversity and Evolutionary Taxonomy, University of Wrocław, Przybyszewskiego 65, 51-148 Wrocław, Poland. E-mail: helena.wesolowska@uwr.edu.pl; ORCID: 0000-0002-4411-1058

${ }^{2}$ Institute of Biology and Earth Sciences, Pomeranian University in Słupsk, Arciszewskiego 22b, 76-200 Słupsk, Poland.

E-mail: konrad.wisniewski.araneae@gmail.com; ORCID: 0000-0002-6780-3292

* corresponding author
}

KEY WORDS: Afrotropical Region, Aranei, Ivory Coast, Myrmarachnini, taxonomy.

КЛЮЧЕВЫЕ СЛОВА: Афротропический регион, Aranei, Республика Кот-д’Ивуар, Myrmarachnini, таксономия.

ABSTRACT. A new species of ant-like jumping spiders (Salticidae) - Belippo eburnensis sp.n. $\left(\mathrm{O}^{7}+\right)$ - is diagnosed and described from Ivory Coast. It belongs to a small genus within the very species-rich tribe Myrmarachnini. This species, as well as B. cygniformis Wanless, 1978 and B. ibadan Wanless, 1978, are assigned to the newly proposed cygniformis species group, of which all three congeners occur in West Africa.

How to cite this article: Wesołowska W., Wiśniewski K. 2020. Belippo eburnensis sp.n., a new ant-like jumping spider (Araneae: Salticidae) from western Africa // Arthropoda Selecta. Vol.29. No.1. P.97-102. doi: 10.15298/arthsel. 29.1.08

РЕЗЮМЕ. Диагностирован и описан новый вид муравьеобразных пауков-скакунчиков (Salticidae) Belippo eburnensis sp.n. $\left(\sigma^{\top}+\right)$ — из Республики Котд’Ивуар. Вид принадлежит к небольшому роду из богатой видами трибы Myrmarachnini. Этот вид, также как B. cygniformis Wanless, 1978 и B. ibadan Wanless, 1978, отнесены к новопредложенной группе видов cygniformis, все представители которой известны из западной Африки.

\section{Introduction}

Belippo Simon, 1910 is a small, Afrotropical genus of ant-mimicking Salticidae containing 12 species [WSC, 2019]. It is a well-defined genus, which was revised by Wanless [1978] who analysed seven Belippo species. Subsequently, five more species have been described [Haddad, Wesołowska, 2013; Wesołowska, Haddad, 2013, 2014; Wesołowska, Wiśniewski, 2015]. Almost all Belippo species are rarely collected, probably due to their small sizes and preferring concealed or hardly accessible habitats; and also due to an overall undersampling of the African salticid fauna. Biology of the majority of Belippo species remains unknown. The available data suggest that members of this genus can occur in leaf litter or on shrubs in the forest understorey and are usually found in association with ants [Roewer, 1942; Wanless, 1978; Wesołowska, Haddad, 2013; present data]. The aim of the present paper is to diagnose and describe a new Belippo species from Ivory Coast.

\section{Material and methods}

The studied specimens are stored in the arachnological collection of the Royal Museum for Central Africa in Tervuren (RMCA ARA). For the spider examination, we have used the standard methods (stereomicroscope, preparation) previously described in Wesołowska \& Wiśniewski [2015]. Colour digital photographs were prepared by Pierre Oger (Waret l'Evêque, Belgium) and reproduced herein with his permission.

\section{Description}

\section{Belippo eburnensis sp.n.}

Figs 1-28, Map.

TYPES. Holotype male (RMCA ARA 246160) from Ivory Coast, vicinity of Man, Mont Toukoui $\left(07^{\circ} 2 \overline{7}^{\prime} 15^{\prime \prime} \mathrm{N}, 07^{\circ} 38^{\prime} 14^{\prime \prime} \mathrm{W}\right)$, $1200 \mathrm{~m}$ a.s.1., Malaise trap, 23.06-1.07.2018, Y. Braet \& A. Gué. PARATYPES: all specimens are from the same locality as above; 2 $0^{7} O^{7}$ together with the holotype (RMCA_ARA_246161), $10^{7}, 8-$ 15.07.2018 (RMCA ARA 246165); 2 万ٓ $\sigma^{7}, 1$ ㅇ, 22-29.07.2018 (RMCA_ARA_246164); 1 + , 26.08-02.09.2018 (RMCA_ARA 246163); $1 \mathrm{O}^{7-}, 15-22.07 .2018$ (RMCA_ARA_246166); $1 \overline{\overline{+}}, 4.1 \overline{1}$. 2018 (RMCA ARA 246162).

ETYMOL̄OGY. The specific name is derived from the Latin name of the country of origin (Ivory Coast $=$ Litus Eburneum). 


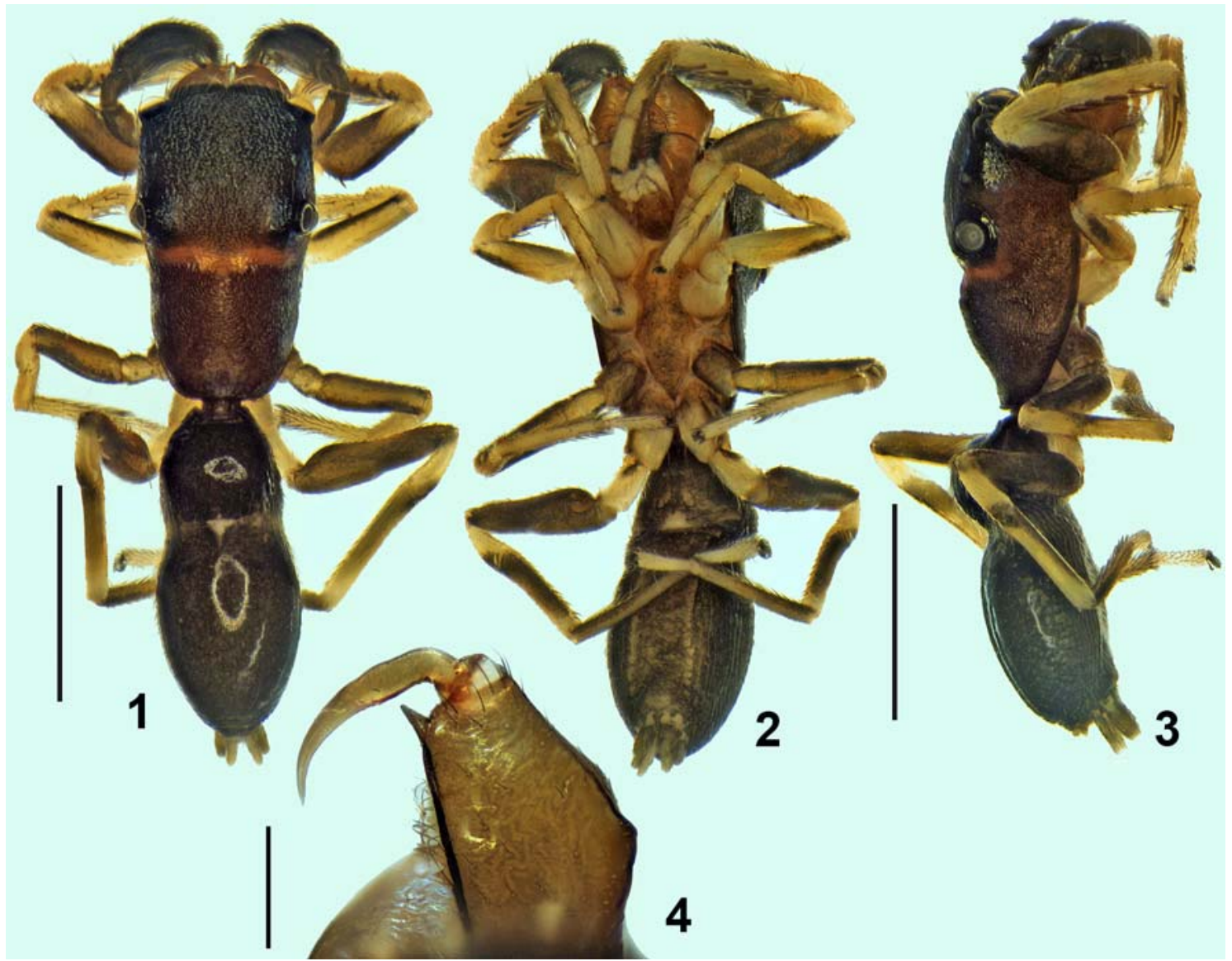

Figs 1-4. Male of Belippo eburnensis sp.n.: 1 - dorsal view; 2 - ventral view, 3 - lateral view, 4 - chelicerae, frontal view. Scale bar: $1 \mathrm{~mm}(1-3), 0.3 \mathrm{~mm}(4)$.

Рис. 1-4. Самец Belippo eburnensis sp.n.: 1 - вид сверху; 2 - вид снизу, 3 - вид сбоку, 4 - хелицеры, вид спереди. Масштаб: 1 мм (1-3), 0,3 мм (4).

DIAGNOSIS. This species is closely related to two $\mathrm{Be}$ lippo species from western Africa: viz., B. cygniformis Wanless, 1978 and B. ibadan Wanless, 1978. The male can be distinguished by the pincer-shaped embolic tip (Figs 9-10, 13-15). The female is similar to that of $B$. ibadan (the female of $B$. cygniformis is unknown) and can be separated by the pear-shaped outline of its abdomen (elongated in $B$. ibadan). The conformation of the female copulatory organs is very similar in both species, but the margin of the central depression is more elongated in B. eburnensis sp.n. There are also some differences in leg colouration between these species: viz., B. eburnensis sp.n. has yellowish coxae in both sexes, except for legs III; in B. ibadan only coxae I are yellowish while others are brown. (Map).

DISTRIBUTION. Known from the type locality only

MEASUREMENTS. (male/female) [mm]. Cephalothorax: length 2.0-2.1/2.2-2.4, width (thoracic part) 0.9-1.0/ $1.3-1.5$, height $0.7-0.8 / 0.7-0.8$. Eye field: length $0.9-1.0$ / $1.0-1.1$, anterior width $1.0-1.1 / 1.2-1.3$, posterior width 1.1 1.2/1.3-1.5. Abdomen: length 2.1-2.3/2.4-2.8, width 1.0 $1.1 / 1.4-1.5$.

MALE. General appearance as in Figs 1-3. Small antlike spider, with slender body. Cephalic and thoracic part of carapace separated by fissure. Cephalic part higher and broader than thoracic part. Carapace black, slightly pitted, light brown streak in constriction, some white hairs at the anterior eye row, a few long dark bristles on sides of eye field and at fovea. Mouth parts and sternum brown. Chelicera dark brown, with distal prolateral spur and second minute spur on lateral keel, groove with three promarginal and six retromarginal teeth (Figs 4, 11, 12). Abdomen black, covered with short black hairs, dorsum covered with two shining scuta, constriction at one-third of abdominal length. Oblique whitish marks on lateral surface of abdomen, venter grey with large dark brown rectangular area. Spinnerets generally dark, posterior lighter. Coxae I and II yellowish, III brown, IV yellowish with dark sides. Leg I blackish, only apical end of tibia and tarsus light (in some specimens leg I lighter, yellowish with black femur only). Leg II whitish yellow, dark streaks along lateral sides of femur. Leg III: dark femur and slightly dimmed metatarsus, remaining segments light. Leg IV: blackish femur, darkened on dorsum of patella apically, two third of tibia dark, metatarsus light with dark streaks along sides. Patella I with two spines, tibia I with five pairs of long ventral spines, metatarsus with two pairs; spination of leg II similar, but on tibia only 3 pairs of ventral spines. Pedipalp blackish, tibial apophysis harpoon-shaped with three additional denticles at its base (Figs 8, 13, 18), tegulum rounded, embolus encircles bulb twice, with pars pendula (Figs 5, 6, 13). Embolic tip pincer-shaped (Figs 5, 6, 9, 10, 13-15), its two tips jointed by a membrane, viewed slightly 


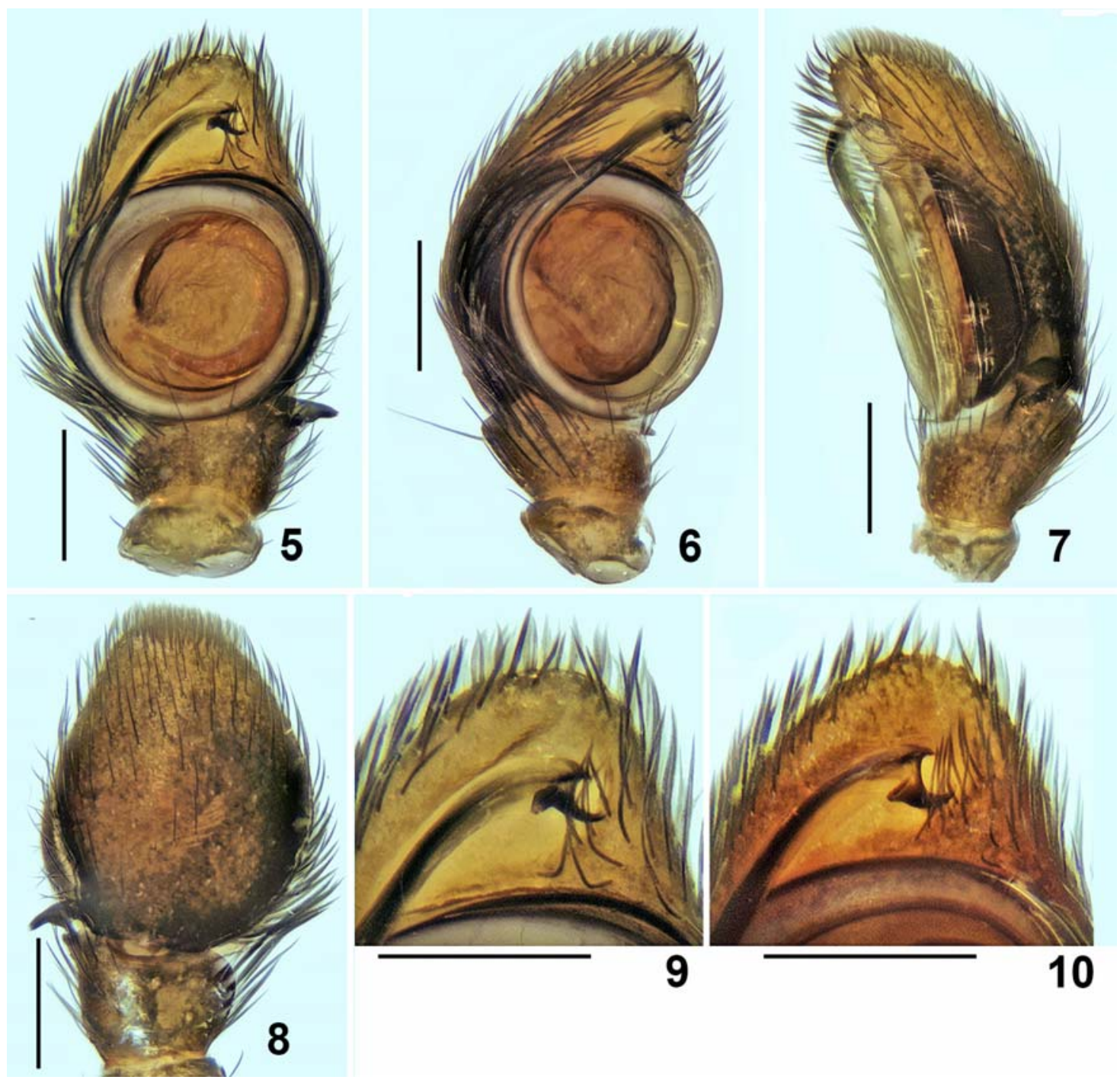

Figs 5-10. Male palp of Belippo eburnensis sp.n.: 5 - ventral view; 6 - ventro-prolateral view; 7 - retrolateral view; 8 - dorsal view; 9-10 - embolic tip (at the other viewing angle). Scale bar: $0.2 \mathrm{~mm}$.

Рис. 5-10. Пальпа самца Belippo eburnensis sp.n.: 5 - вид снизу; 6 - вид снизу-сзади-сбоку; 7 - вид сзади-сбоку; 8 - вид сверху; 9-10 - кончик эмболюса (под другим углом). Масштаб: 0,2 мм.

from below it looks like a halberd (Figs 16,17). Two stout bristles on the cymbium tip (Fig. 13).

FEMALE. General appearance as in Figs 19-21. Similar to the male, abdomen pyriform, wider behind constriction, covered with thin hairs. Colouration generally black, brighter at carapace furrow, lateral light marks in abdominal constriction, venter of abdomen grey. Chelicera with four teeth on promargin (one of them placed separately) and six on retromargin (Fig. 26). Coxae light, except coxae III that are brown. Legs slender, generally blackish with dirty yellow patellae and distal segments, femora II yellowish with dark stripes along sides, similar streaks on tibia IV. Pedipalps oblate, black. Epigyne weakly sclerotized, with a large central depression, pockets placed at sides of the depression (Fig. 27), the conformation is slightly changeable (Figs 2224). Seminal ducts membranous, thin, long, meandering; spermathecae composed of two spherical chambers connected with long ducts, second chamber surrounded by amorphous glandular tissue (Figs 25, 28).
COMMENTS. Three western African species of Belippo, namely $B$. cygniformis, B. ibadan and B. eburnensis sp.n., are closely related. $B$. ibadan has a slimmer body than in two related species. The female copulatory organs of $B$. eburnensis sp.n. and B. ibadan are very similar and hardly distinguishable, whereas the female of B. cygniformis is yet unknown. Some epigynal features that can be used in distinguishing the species, such as the conformation of the extremely long and delicate seminal ducts, could be misleading, as they strongly vary depending on how the epigyne was desiccated. The other problem concerns specimen colouration, which sometimes varies within some Myrmarachnini species. The male palpal organs in these species are rather similar and differ only in the shape of the embolic tip. It is pointed in $B$. ibadan, slightly broadened with a shallow notch in B. cygniformis, and clearly pincer-like in B. eburnensis sp.n. Based on morphological characters, the two latter species are most similar to each other. In our opinion, it is very likely that these three species represent a single 

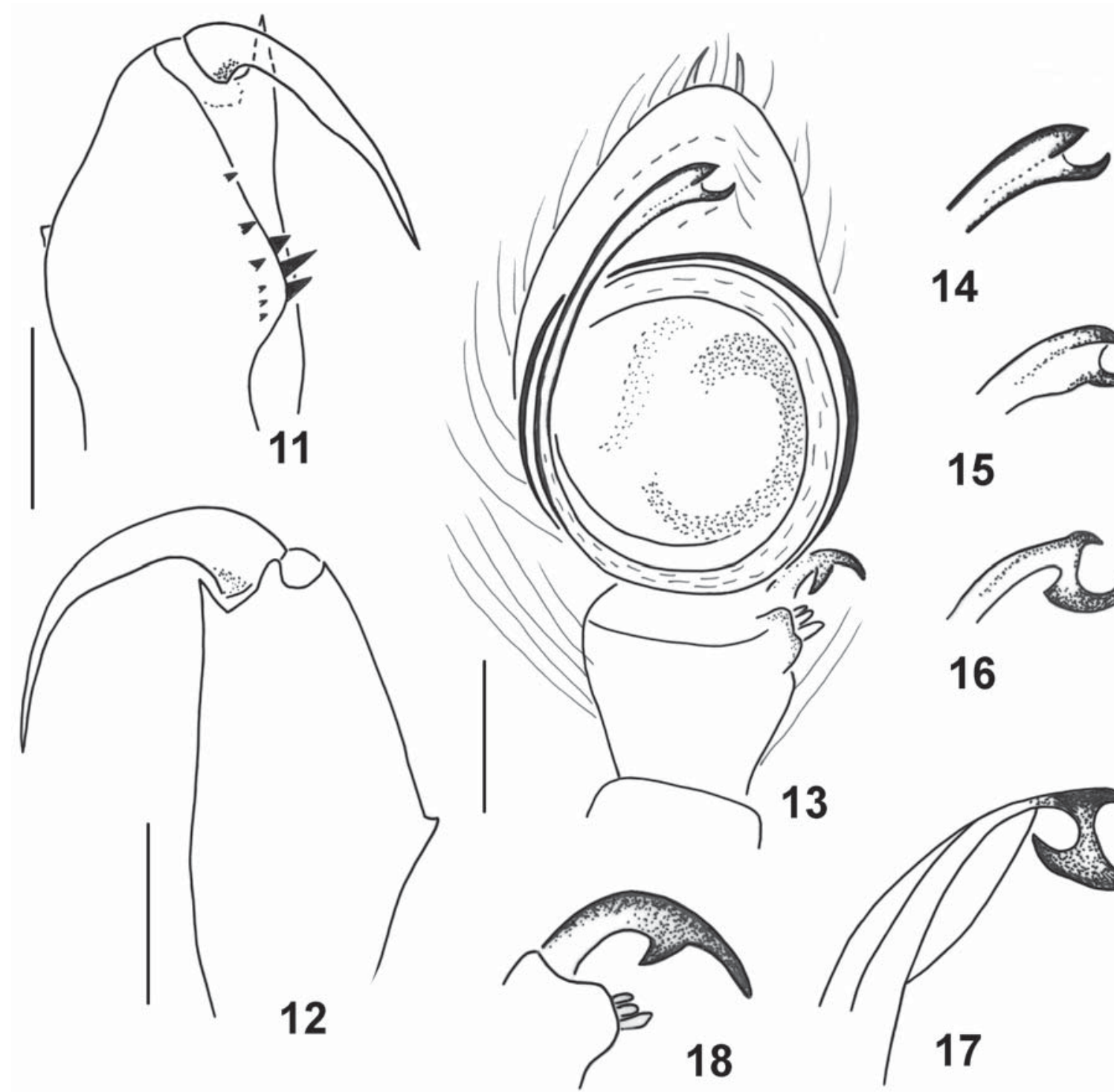

14

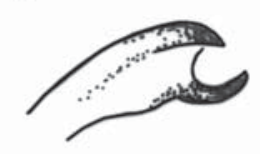

15

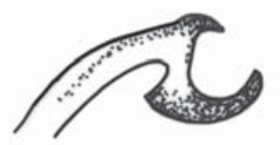

16

Figs 11-18. Male of Belippo ebrunensis sp.n.: 11 - chelicera, ventrally; 12 - ditto, dorsally; 13 - palp, ventrally; $14-17$ - embolic tip (at different views); 18 - tibial apophysis, ventral view. Scale bar: $0.3 \mathrm{~mm}(11,12), 0.2 \mathrm{~mm}(13)$.

Рис. 11-18. Самец Belippo ebrunensis sp.n.: 11 - хелицера, вентрально; 12 - то же, дорсально; 13 - пальпа, вентрально; $14-$ 17 - кончик эмболюса (в разных видах); 18 - вырост годени пальпы, вентрально. Масштаб: 0,3 мм (11, 12), 0,2 мм (13).

phylogenetic lineage and can be united in the newly proposed cygniformis species group. Yet, the geographic localities of all three species are close to each other (Fig. 29). Although the available data on the preferred microhabitats by Belippo species are very limited, the three related species seem to prefer slightly different microhabitats. B. eburnensis sp.n. was collected by Malaise trap and is likely to occur on shrubs in the forest understorey, $B$. ibadan is known to occur in leaf litter [Wanless, 1978; Wesołowska, RussellSmith, 2011], whereas B. cygniformis was reported as occurring in tree canopies [Wanless, 1978].

Acknowledgements. We would like to thank Prof. Bamba Aboudramane, Director of Research at the Ministry of Higher Education and Scientific Research, Ivory Coast, who issued the research permit (080/MESRS/DGRI/DR of April 2018) and the export permit (094/MESRS/DGRI/DR of 02
July 2018), as well as, Mr Mamadou Sangare, Director General of SODEFOR - Société de Développement des Forets, Ivory Coast, who issued the access permit for the classified forest of Mount Tonkoui (01514-18/DT/SDAP/ DAN/GKS of 4 April 2018). Without their positive decisions collecting spiders for this study would be impossible. We are also grateful to Pierre Oger (Waret l'Evêque, Belgium) for his kind permission to use his digital photographs in the paper; they are also available online at: https:// arachno.piwigo.com/.

\section{References}

Haddad C.R., Wesołowska W. 2013. Additions to the jumping spider fauna of South Africa (Araneae: Salticidae) // Genus. Vol.24. No.3-4. P.459-501.

Roewer C.F. 1942. Opiliones, Pedipalpi und Araneae von Fernando Poo. 21. Beitrag zu den wissenschaftlichen Ergebnissen der 


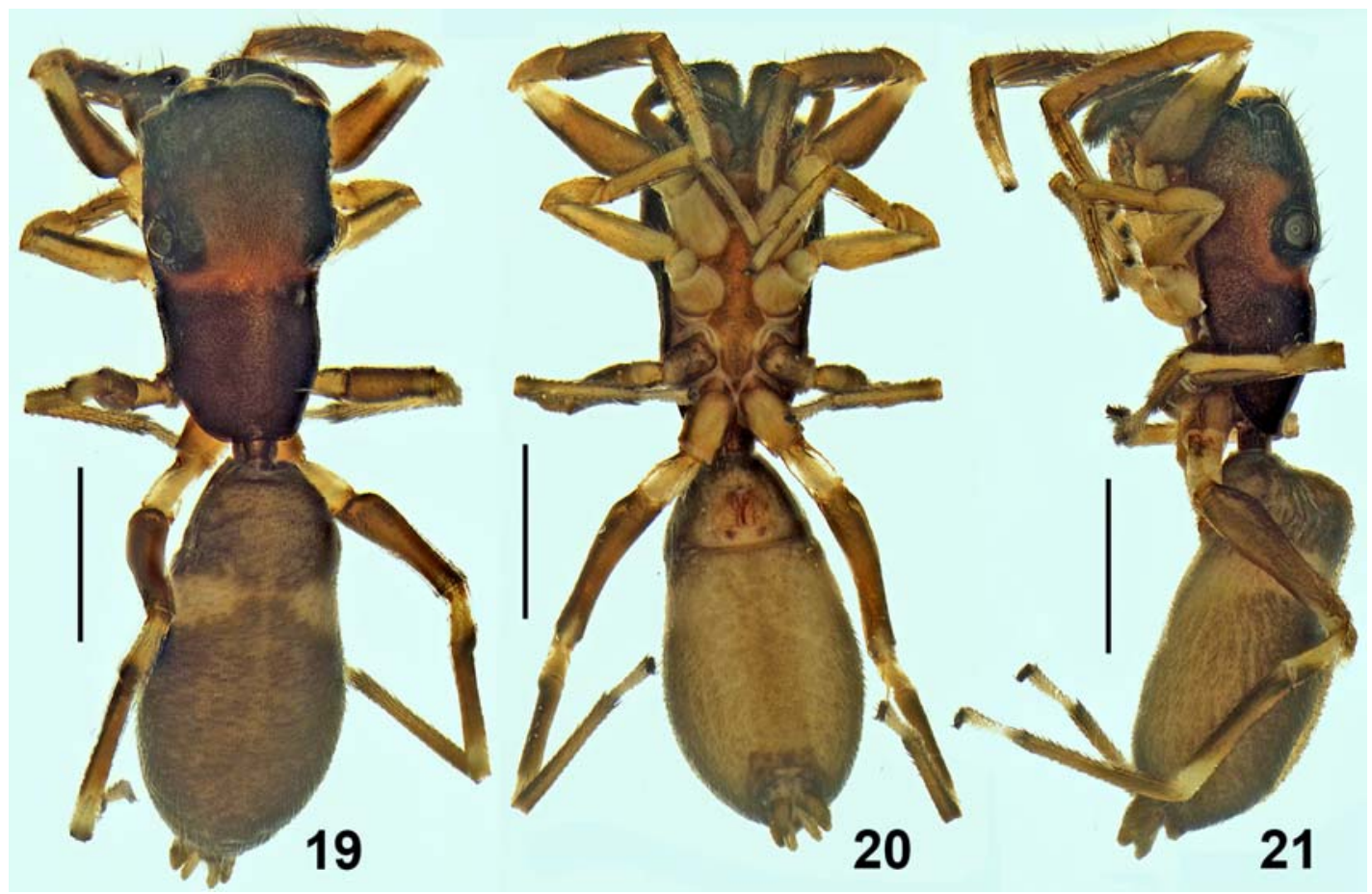

Figs 19-21. Female of Belippo eburnensis sp.n.: 19 - dorsal view; 20 - ventral view; 21 - lateral view. Scale bar: $1 \mathrm{~mm}$. Рис. 19-21. Самка Belippo eburnensis sp.n.: 19 - вид сверху; 20 - вид снизу; 21 - вид сбоку. Масштаб: 1 мм.

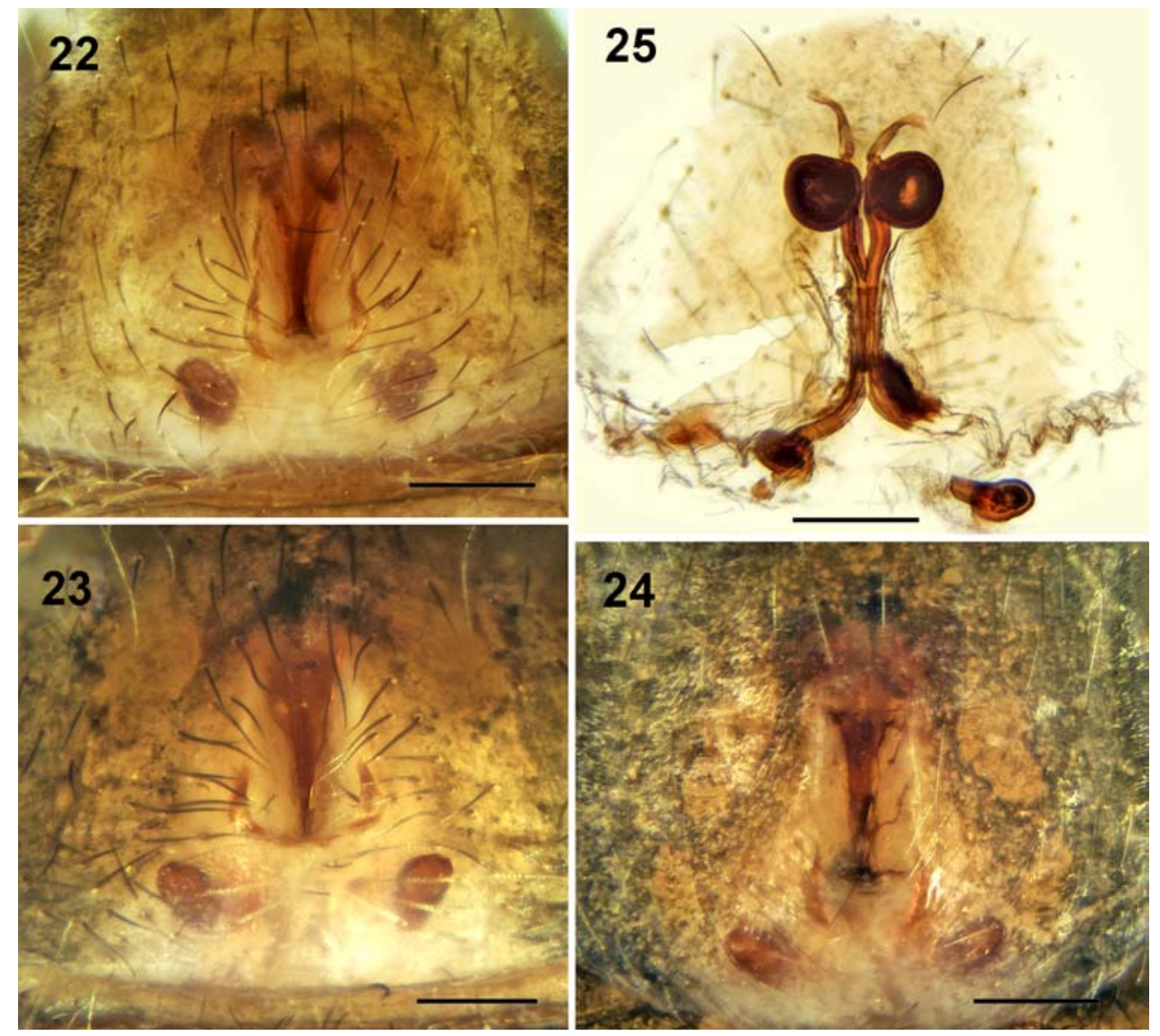

Figs 22-25. Female copulatory organs of Belippo eburnensis sp.n.: 22-24 - epigyne, variation; 25 - spermathecae. Scale bar: $0.2 \mathrm{~mm}$. Рис. 22-25. Копулятивные органы самки Belippo eburnensis sp.n.: 22-24 - эпигина, изменчивость; 25 - сперматеки. Масштаб: 0,2 мм. 


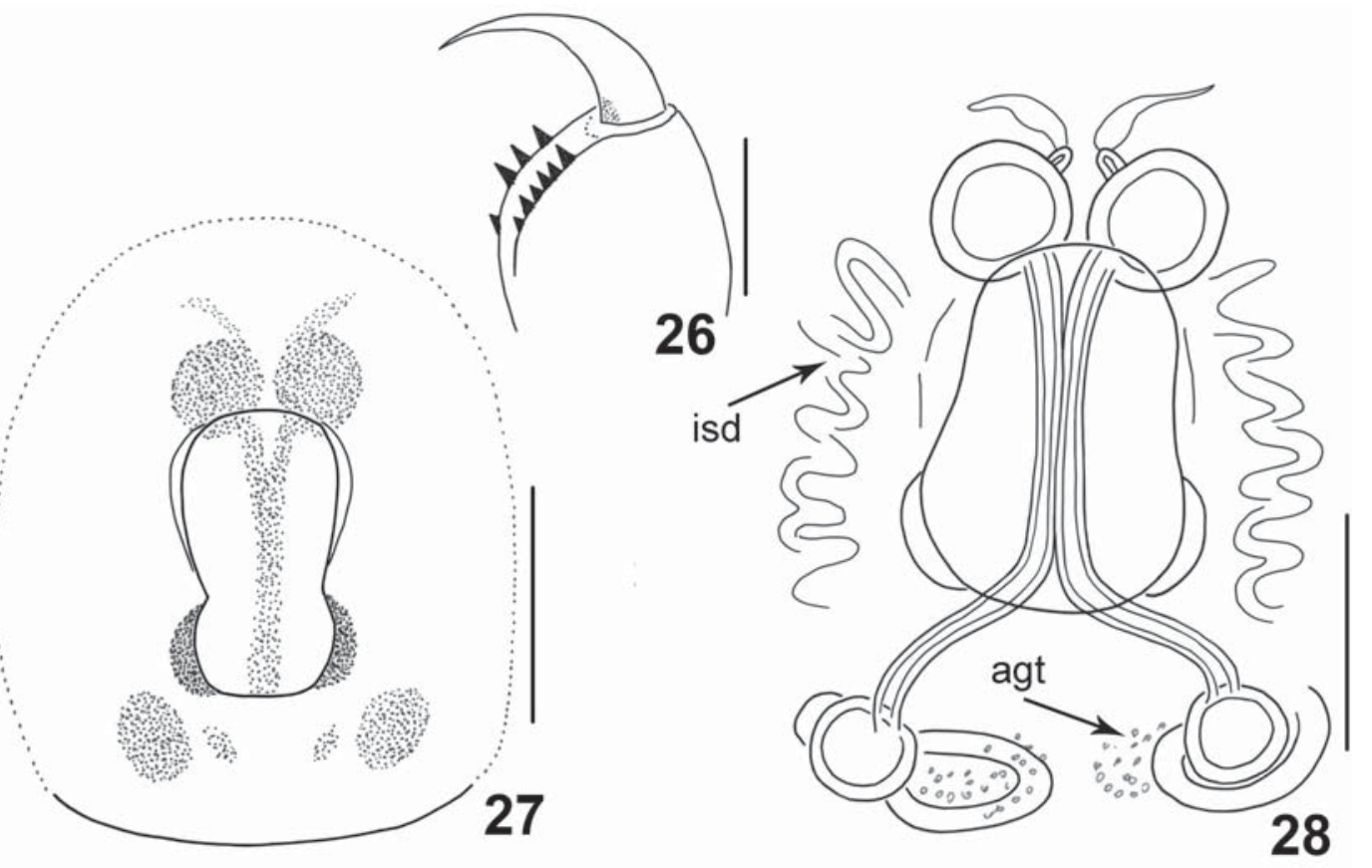

Figs 26-28. Female of Belippo eburnensis sp.n.: 26 - chelicera, ventral view; 27 - epigyne, ventral view; 28 - spermathecae. Abberviations: isd - initial part of seminal ducts, agt - amorphous glandular tissue. Scale bar: $0.3 \mathrm{~mm}(26), 0.2 \mathrm{~mm}(27,28)$.

Рис. 26-28. Самка Belippo eburnensis sp.n.: 26 - хелицера, вид снизу; 27 - эпигина, вид снизу; 28 - сперматеки. Сокращения: isd - начальная часть оплодотворительного канальца, agt - аморфная, гландулярная ткань. Масштаб: 0,3 мм (26), 0,2 мм $(27,28)$.

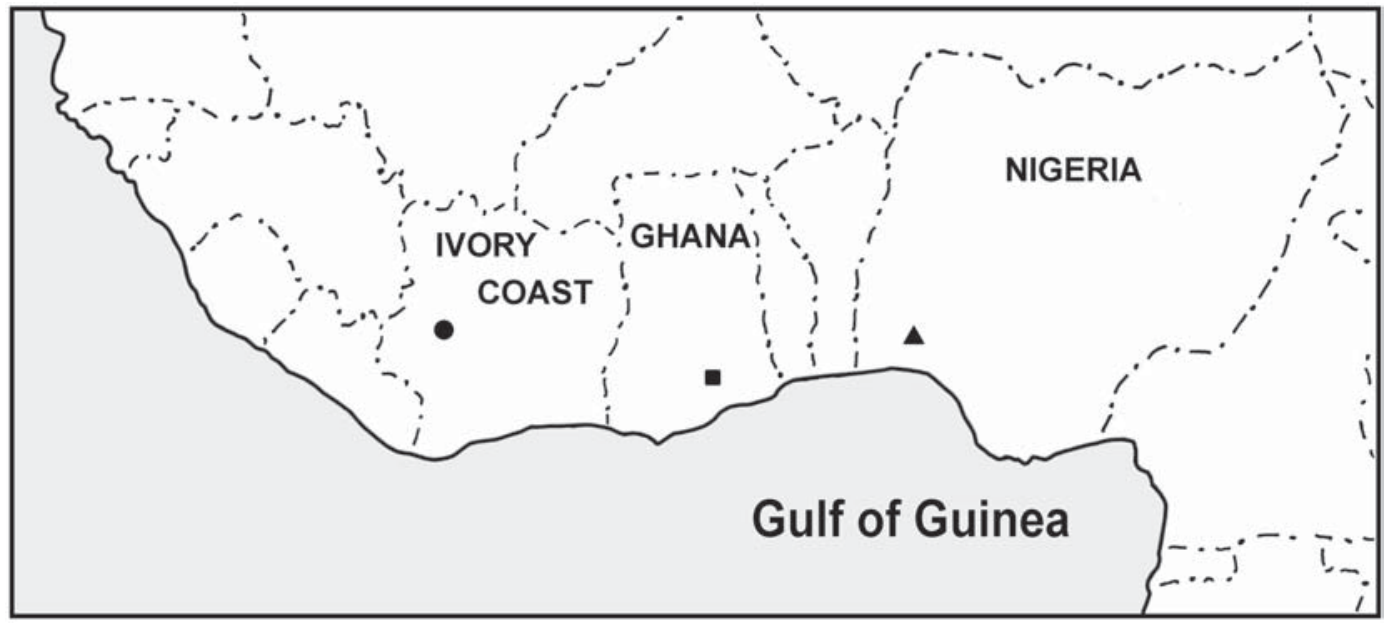

Map. Distribution of three Belippo species: circle - B. eburnensis, square - B. cigniformis, triangle - B. ibadan.

Карта. Распространение трех видов Belippo: кружок - B. eburnensis, квадрат - B. cigniformis, треугольник - B. ibadan.

Westafrika Expedition Eidmann 1939/40 // Veröffentlichungen aus dem Deutschen Kolonial- und Übersee-Museum Bremen. Bd.3. No.3. S.244-258.

Wanless F.R. 1978. A revision of the spider genera Belippo and Myrmarachne (Araneae: Salticidae) in the Ethiopian region // Bulletin of the British Museum of Natural History (Zoology). Vol.33. P.1-139.

Wesołowska W., Haddad C.R. 2013. New data on the jumping spiders of South Africa (Araneae: Salticidae) // African Invertebrates. Vol.54. No.1. P.177-240. doi:10.5733/afin.054.0111

Wesołowska W., Haddad C.R. 2014. An overview of the jumping spiders of Lesotho (Araneae: Salticidae), with descriptions of six new species // African Invertebrates. Vol.55. No.2. P.229268.
Wesołowska W., Russell-Smith A. 2011. Jumping spiders (Araneae: Salticidae) from southern Nigeria // Annales Zoologici, Warszawa. Vol.61. No.3. P.553-619. doi:10.3161/ 000345411 X603409

Wesołowska W., Wiśniewski K. 2015. New data on Belippo and Myrmarachne of Kenya (Araneae: Salticidae: Myrmarachninae) // Zootaxa. Vol.3980. No.4. P.547-561. doi:10.11646/ zootaxa.3980.4.5

WSC 2019. World Spider Catalog, version 20.0. Natural History Museum Bern, online at http://wsc.nmbe.ch, accessed on 25.07.2019.

Responsible editor D.V. Logunov 